UNI TED STATES

DEPARTMENT OF THE INTERIOR

GEOLOGICAL SURVEY

THE POTENTIOMETRIC SURFACE OF THE MAGOTHY AQUIFER ON IONG ISLAND,

NEW YORK, IN MARCH 1975

ith ocat

By K. R. Prince

Open-File Report 76-536

Prepared in cooperation with the

New York State Department of Environmental Conservation,

Nassau County Department of Public Works,

Suffolk County Department of Environmental Control, and

Suffolk County Water Authority

Mineola, New York

April 1976 


\section{CONTENTS}

Page

Factors for converting English units of measure to International sys tem . (SI) units:

4

Abstract 5

Introduction 6

Acknowledgments

Method 8

Results 9

References cited. 12 
ILLUSTRATION

(Plate is in pocket)

Plate 1. Map showing the potentiometric surface of the Magothy aquifer on Long Island, New York, in March 1975.

TABLE

Table 1. Water levels in selected wells screened in the Magothy aquifer

FACTORS FOR CONVERTING ENGLISH UNITS

OF MEASURE TO INTERNATIONAL SYSTEM (SI) UNITS

$\begin{array}{lcl}\text { Multiply English units } & \text { by } & \text { To obtain SI units } \\ \text { inches } & 25.4 & \text { millimetres } \\ \text { feet } & .3048 & \text { metres } \\ \text { miles } & 1.609 & \text { kilometres } \\ \text { million gallons per day } & 3,785 & \text { cubic metres per day }\end{array}$




\title{
THE POTENTIOMETRIC SURFACE OF THE MAGOTHY AQUIFER ON LONG ISLAND, NEW YORK, IN MARCH 1975
}

\section{By}

K. R. Prince

\begin{abstract}
A map showing the potentiometric surface of the Magothy aquifer was drawn from water-level measurements made in March 1975. These measurements indicated a range in altitude of the potentiometric surface from more than 25 feet (7.62 metres) below mean sea level in Queens County to more than 80 feet (24.38 metres) above mean sea level in Nassau County.
\end{abstract}




\section{INTRODUCTION}

Ground water is the sole source of freshwater for over 3 million residents of Long Island. The water supply is mainly withdrawn from three major aquifers--the upper glacial, the Magothy, and the Lloyd.

The Magothy aquifer is the principal aquifer. It is generally overlain by the upper glacial aquifer and is underlain by the Raritan clay, which in.turn overlies the Lloyd aquifer. Along the south shore of Long Island, the Magothy aquifer is locally confined by the overlying Gardiners Clay.

During 1974, about 250 million gallons $(946,000$ cubic metres) of water was pumped daily from the Magothy aquifer for public supply and industrial use. Because of the large pumpage, the changes in potentiometric head are monitored, as they indicate changes in storage and water movement in the aquifer.

The purpose of this report is to describe the March 1975 position of the potentiometric surface of the Magothy aquifer. A potentiometric surface is the surface that represents the static hydraulic head in the aquifer. The potentiometric surface shown on plate 1 is the altitude at which water would have_stood-in tightly cased wells-in March 1975 . ..= Changes in the potentiometric surface generally result from variations in the amount of water either entering or discharging from the aquifer. Large head changes are usually the effect of an increase or decrease in pumpage. 
The cooperation of the following water suppliers in obtaining these water levels is appreciated: Albertson Water District, Bethpage Water District, Citizens Water Company, East Meadow Water District, Freeport Water District, City of Glen Cove, Greenlawn Water District, Village of Hempstead, Hicksville Water District, Jamaica Water Supply Company, Jericho Water District, Levittown Water District, Locust Valley Water District, Long Island Water Corporation, Manhasset-Lakeville Water District, Massapequa Water District, Village of Mineola, Nassau Country Club, Village of old Westbury, Oyster Bay Water District, village of Plandome, Plainview Water District, Port Washington Water District, Riverhead Water District, Village of Rockville Centre, Village of Sands Point, Sea Cliff Water Company, South Huntington Water District, Suffolk County Water Authority, Uniondale Water District, Utilities and Industries Corporation, and westbury Water District.

Previous potentiometric maps of the Magothy aquifer are in published reports by Kimmel (1971) and Soren (1971), and in an open-file report by Koch and Koszalka (1972). 
This report summarizes data obtained from nearly simultaneous water-level measurements made in March 1975 in 120 wells screened in the Magothy aquifer or other aquifers reflecting Magothy heads. A large number of the wells used in the study are in the western half of Long Island, where the demand for water is greater because of dense population.

Ninety-six of the wells that were measured are parts of public supply systems, and many of these wells are in continuous operation. Operating public supply wells measured in this study were turned off for a minimum of 24 hours prior to measurement. This was done so that the water levels would reflect potentiometric heads in the aquifer rather than pumping levels in the wells. Thirty-nine of the wells in Suffolk County were measured at or near the time of this study by the air-line pressure method and are indicated as such on plate 1. Because the accuracy of air-line measurements may vary, their readings are rounded to the nearest foot.

The remaining 24 wells are unpumped observation wells in which aquifer heads are recorded regularly. In observation wells near shorelines, where potentiometric levels are affected by tides, levels at high tide were used. 
Location of the wells in which water levels were measured and the altitude of the water level (potentiometric head) are shown on plate 1. Selected water-level measurements are compared with previous water levels in table 1. Water-level measurements from March 1975, together with prior potentiometric-surface maps of the Magothy aquifer, were used to define'the potentiometric surface shown in plate 1.

Pumping has caused a major depression in the Magothy aquifer's potentiometric surface throughout most of Queens County. This depression is also discussed by Soren (1971, p. 15) and by Kimmel (1971, p. 226). In 1961, the lowest water levels were just over 10 feet (3.0 metres) below mean sea level. By 1968, the depression had increased to more than 15 feet (4.5 metres) below mean sea level (Soren, 1971, plate 2, c and F). The March 1975 measurements indicate that the waterlevel depression has deepened to approximately 25 feet ( 7.6 metres) below mean sea level. Available records show this to be approximately equal to the lowest water levels on record for this area and about 10 feet ( 3.0 metres) below the 1972 water level (Koch and Koszalka, 1972) . : . 
Table 1.--Water levels in selected wells screened in the Magothy aquifer

(Water levels are in feet above or below (-) mean sea level;

letters in well numbers refer to counties in which wells are located--Q, Queens County; N, Nassau County; and S, Suffolk County)

\begin{tabular}{|c|c|c|c|}
\hline \multirow{2}{*}{ Well number } & \multicolumn{2}{|c|}{ Water level } & \multirow{2}{*}{ Net change } \\
\hline & March 1974 & March 1975 & \\
\hline$Q 471$ & 14.70 & 14.37 & -0.33 \\
\hline Q2332 & -16.71 & -17.01 & -0.30 \\
\hline$Q 2409$ & -15.74 & -24.39 & -8.65 \\
\hline 22410 & 5.96 & 2.00 & -3.96 \\
\hline Q2432 & -26.83 & -28.33 & -1.50 \\
\hline N180 & I/ 17.36 & 17.67 & 0.31 \\
\hline N1613 & I/ 6.98 & 6.90 & -0.08 \\
\hline N3861 & -4.64 & -4.28 & 0.36 \\
\hline N3867 & 2.40 & 2.10 & -0.30 \\
\hline$N 4150^{2}=s$ & $6.83=$ & $7.32 \cdots$ & $0.49 .=-$ \\
\hline N6510 & -2.67 & -2.61 & 0.06 \\
\hline S6455 & 39.81 & 38.91 & -0.90 \\
\hline S 22577 & 42.10 & 41.72 & -0.38 \\
\hline S 34272 & 20.78 & 21.97 & 1.19 \\
\hline 534894 & 46.07 & 45.23 & -0.84 \\
\hline
\end{tabular}

1/ April 1974. 
The highest known head in the Magothy aquifer, approximately 85 feet (25.9 metres) above mean sea level, occurs in northeastern Nassau County. Water levels in the Magothy aquifer for the remainder of Long Island show only minor changes since 1972 (Koch and Koszalka, 1972). 
Kimmel, G. E., 1971, Water-level surfaces in the aquifers of western Long Island, New York, in 1959 and 1970: U.S. Geol. Survey Prof. Paper 750-B, p. 224-228.

Koch, Ellis, and Koszalka, E. J., 1972, Potentiometric surface of the lower part of the Magothy aquifer in March 1972: U.S. Geol. Survey open-file rept., 1 plate. Soren, Julian, 1971, Ground-water and geohydrologic conditions in Queens County, Long Island, New York: U.S. Geol Survey WaterSupply Paper 2001-A, 39 p. 